\title{
Gendering transitional justice processes in Africa: a feminist advocacy approach to truth commissions
}

\author{
Elias O. Opongo
}

\begin{abstract}
Highlighting the place and role of women in transitional justice processes draws attention to two main aspects: the need for a holistic approach to transitional justice processes, and paying attention to the sensitive nature of gender-based violence in the whole cycle of truth commissions from articulation of the mandate of the commission, composition of the commissioners, categorisation of crimes, to the writing and implementation of the final report. A feminist advocacy approach to transitional justice is framed under a critical feminist strategy that draws attention to diverse forms of human rights violations against women in situations of conflict; structures of exclusion of women's concerns; the agency and presence of women in truth commission processes. Hence, discourse on gendering transitional justice processes has recently emerged, especially given that women have been targeted in conflict situations, giving rise to sexual and gender-based violence, and indiscriminate killing of women despite their non-combatant role. This article discusses the extent of marginalisation of cases of women's gross human rights violations in truth commission processes, while acknowledging positive attempts made so far, through critical feminism, to include women's concerns in these processes.
\end{abstract}

Keywords: Transitional justice; feminism, critical feminism, truth commissions, gender, gendering, sexual and gender-based violence, human rights violations.

Note on the author: Elias O. Opongo is a senior lecturer at Hekima University College and the director of the Centre for Research, Training and Publications (CRTP) at the same university. His main research interests include: transitional justice, post-conflict reconstruction, statebuilding and democracy, and religious extremism and violence. He holds a $\mathrm{PhD}$ in Peace Studies from the University of Bradford, U.K. and MA in International Peace Studies from the University of Notre Dame, USA.

ORCID ID: https://orcid.org/0000-0002-3320-7222

(C) The author(s) 2021. This is an open access article licensed under a

Creative Commons Attribution-NonCommercial-NoDerivs 4.0 Unported License 


\section{Introduction}

African societies have been dealing with transitional processes in their quest to come to terms with the traumas of slavery, colonialism, apartheid, systematic repression, and civil war. ${ }^{1}$ With the emerging post-colonial conflicts and wars in the African continent in the past few decades, the discourse on gender in transitional justice processes has recently emerged as an important issue of concern, particularly in relation to inclusion in truth commissions of cases of human rights violations against women. The rising number of women victims of violence has been underscored by the practice of sexual and gender-based violence targeting women in situations of conflict, the indiscriminate killing of women despite their non-combatant role, and forced bondage of women as wives or concubines to militia groups. ${ }^{2}$ Wartime sexual violence has gained prominence in human security and historical studies, peace studies, and post-conflict reconstruction processes. ${ }^{3}$

Numerous approaches to transitional justice have been adopted, including the establishment of war crime tribunals and truth and reconciliation commissions (TRCs) that have been implemented in South Africa, Sierra Leone, Kenya, and Liberia, among other countries. Additionally, the international community's concern about human rights violations during war has led to the establishment of the International Criminal Court (ICC), where a number of African leaders and warlords involved in war crimes have been prosecuted. The ICC has paid special attention to violence against women, and established a legal framework for the identification, investigation, and prosecution of such crimes. Local initiatives to address war crimes have also been of great significance in the continent, with Rwanda making use of the gacaca courts to ensure that victims of violence in the 1994 genocide get justice.

This article draws attention to a critical feminist advocacy approach to truth commission processes, focused on diverse forms of human rights violations against women in situations of conflict, structures of exclusion of women's concerns, and agency and presence in transitional justice processes. The article notes that earlier truth commissions, such as in Argentina and Chile, paid minimal attention to categories of violence against women. However, later ones in South Africa, Kenya, Sierra Leonne, Ghana, and Liberia considered inclusion of violence against women. The inclusion of different forms of violence against women in truth commissions in Africa can largely be attributed to critical feminist advocacy that has been advanced by different civil society and women human rights groups, local and international

\footnotetext{
${ }^{1}$ African Union (2019).

${ }^{2}$ Denov (2006); see also Tripp (2010).

${ }^{3}$ Denov (2006); see also Human Rights Watch (2003).
} 
organisations, as well as individuals committed to advocating for the rights of women. There is, however, a lot of work that still needs to be done in deconstructing local justice systems to pay more attention to prosecuting cases of violence against women.

In general, the term 'gender' has diverse implications as a socially constructed concept. As such, the term 'gender' can be instrumentalised to imply different social, political, economic, or religious connotations and underpinnings. For the purposes of discussion in this article, the term 'gender' will refer to social differentiations of women and men, with the intention of highlighting the place of women in truth commission processes. This is complemented by a critical feminist approach that takes into account the social dynamics of male-female interactions, power relations, and women's agency in implementation structures of truth commissions in Africa.

The discussion in this article will first focus on a conceptualisation of the transitional justice process, and its broader definitions and articulations, with particular reference to truth commissions. Then it moves on to unpacking the theoretical framework that will guide the discussion, and ends with an analysis of critical feminist advocacy on the inclusion of human rights violations against women in the truth commission processes.

\section{Conceptualising transitional justice processes}

Transitional justice refers to broad processes of post-conflict reconstruction largely based on addressing past crimes, holding accountable individuals and institutions that have committed crimes, and ensuring that victims attain justice. The International Center for Transitional Justice (ICTJ) defines transitional justice as 'ways in which countries emerging from periods of conflict and repression address large-scale or systematic human right violations so numerous and so serious that the normal justice system will not be able to provide an adequate response'. ${ }^{4}$ This definition acknowledges the immensity of gross human rights violations that often local justice systems may not be able to handle. More and more nations have come to realise that 'the demand that every polity confront its past in an open-minded and critical fashion has become widely accepted'. ${ }^{5}$ In the words of Kofi Annan, the former United Nations (UN) Secretary General, sovereignty is responsibility and as such nations have the responsibility to protect their citizens. ${ }^{6}$ The concept of 'responsibility to protect' was further developed and adopted by the United Nations as a principal modus operandi

\footnotetext{
${ }^{4} \mathrm{ICTJ}$ (n.d.).

${ }^{5}$ Bakiner (2016: 14).

${ }^{6}$ United Nations (n.d.).
} 
for states, while the UN and regional governments had the responsibility to intervene in situations where a state had failed to protect its own citizens. ${ }^{7}$

Transitional justice, however, goes beyond simply holding the state responsible for the protection of its citizens, and brings awareness to common responsibility that cuts across all sectors of society. In other words, individuals and institutions responsible for the crimes committed are held accountable for their actions. In a sense, the transitional justice process attempts to bring a closure to historical injustices, while maintaining a delicate balance of sustaining peace given the fact that in most cases perpetrators may still have a strong influence, and could destabilise the country if not properly handled.

The African Union (AU), in 2019, adopted a Transitional Justice Policy (TJP) as 'an African model and mechanism for dealing with not only the legacies of conflicts and violations, but also governance deficits and developmental challenges with a view to advancing the noble goals of the AU's Agenda 2063, The Africa We Want' ${ }^{8}$ The AU commitment to transitional justice processes reflects a new shift to social-political accountability and recognition that conflicts tend to retard development, and unaddressed historical injustices weaken social cohesion, and subsequent nationbuilding efforts.

Olsen et al. observe that there are four possible approaches to transitional justice process. ${ }^{9}$ First is a maximalist approach that emphasises prosecution of past crimes and the rendering of retributive justice to the victims; second is the moderate approach that advocates for truth commissions with a focus on a "victim-oriented restorative justice mechanism that holds perpetrators accountable through nonjudicial processes'; $;{ }^{10}$ third is the minimalist approach that is cautious and prefers not to hold perpetrators accountable, and instead opts for amnesty; fourth is a holistic approach that brings together the three approaches above, depending on the socio-political imperatives of a particular context. In other words, what Olsen et al. are proposing here is that the transitional justice process is a delicate balance, and the instituted process ought to juggle between rendering justice to the victims, holding perpetrators accountable, and sustaining peace in a fragile post-conflict context. The discussion in this article focusses on truth commissions as a tool for a transitional justice process.

Truth commissions have become practical platforms for peace sustainability in fragile post-conflict societies. The commission brings together victims and perpetrators

\footnotetext{
${ }^{7}$ Ibid.

${ }^{8}$ African Union (2019).

${ }^{9}$ Olsen et al. (2010: 982-3).

${ }^{10} \mathrm{Ibid}$.
} 
with the intention of discovering the truth, and rendering justice to victims, and accountability to perpetrators. The operating definition for the truth commissions in this discussion is the one provided by Mark Freeman, who defines a truth commission as:

an ad hoc, autonomous, and victim-centered commission of inquiry set up in and authorized by a state for the primary purposes of (1) investigating and reporting on the principal causes and consequences of broad and relatively recent patterns of severe violence or repression that occurred in the state during determinate periods of abusive rule or conflict, and (2) making recommendations for their redress and future prevention. ${ }^{11}$

The above definition is complemented by the conceptualisation of truth commissions advanced by Eric Wiebelhaus-Brahm who observes that there are four main characteristics of truth commissions: first, that they tend to focus strongly on recent past human rights abuses; second, that they investigate crimes committed during a particular political period (such as civil war, political upheaval, or rule by dictatorial regime); third, they are temporary and may run for a span of six months to two years; fourth, truth commissions, while independent, are also officially sanctioned, often within legal frameworks. ${ }^{12}$

While truth commissions have had a tremendous impact on post-conflict reconstruction, there have been concerns that the commissions have not adequately addressed human rights violations against women in situations of conflict. Gendered agency in the transitional justice process is fundamentally important. Annika Björkdahl and Johanna Selimovic argue that gendered agency 'delivers more credibility and substance to the notion of just-peace and enables a theoretical conceptualization more reflective of justice concerns that emanate from the "bottom up" ${ }^{13}$ It is therefore crucial to consider a gendered approach to transitional justice, and particularly in the truth commission processes, given that women have often suffered the brunt of war and conflict.

Diverse research has shown that war is gendered ${ }^{14}$ and that in recent years, women and children have been the main victims. For example, according to Jan Pettman, 80 per cent of the casualties in World War I were soldiers who were largely men. ${ }^{15}$ However, only 50 per cent of the victims in World War II were soldiers. Furthermore, soldiers accounted for only 20 per cent of deaths in the Vietnam War, whereas other

\footnotetext{
${ }^{11}$ Freeman (2006: 18); see also Hayner (2001: 14).

${ }^{12}$ Wiebelhaus-Brahm (2010: 14).

${ }^{13}$ Björkdahl \& Selimovic (2015: 166).

${ }^{14}$ Pankhurst (2007); see also Kandiyoti (1998: 274-90).

${ }^{15}$ Pettman (1996: 89).
} 
casualties were civilians, mostly women and children. ${ }^{16}$ By the 1990s, 90 per cent of deaths were mainly civilians, with women and children again making up the majority. ${ }^{17}$ It is estimated that between 215,000 and 257,000 women were victims of sexual assault during the war in Sierra Leone. ${ }^{18}$ Hence, the gendering of violence has rendered women more vulnerable, particularly in situations of conflict.

The UN Security Council Resolution 2106 (2013) on conflict-related sexual violence focuses, predominantly, on investigating sexual and gender-based violence (GBV) during and after conflict in an attempt to prevent future atrocities. ${ }^{19}$ Notwithstanding its importance, this Resolution, as is the case with many other similar initiatives, addresses the important issues of investigating, documenting, and litigating past acts of violence, especially GBV, but does not necessarily create much scope for building the necessary platforms to create the right conditions for women's diverse voices to be heard, their varied experiences acknowledged, and their diverse needs recognised ${ }^{20}$ In order to put into effect the previous Resolution 1889 (2009), stressing the participation of women and creating a commitment to provide resources for 'advancing gender equality', there is need for greater recognition of gender equality in all spheres of life (including social, economic, and political) for the future of the application and implementation of transitional justice. ${ }^{21}$

The UN Security Council Resolution 1325 of the year 2000 calls on 'all parties to armed conflict to take special measures to protect women and girls from gender-based violence, particularly rape and other forms of sexual abuse, and all other forms of violence in situations of armed conflict'. ${ }^{22}$ The focus on sexual and gender-based violence (SGBV) has raised awareness of the need to develop new frameworks for addressing such situations of violence in post-conflict contexts.

To a great extent, transitional justice and peace-building practices tend to reentrench gendered hierarchies, based on male dominance, by ignoring women or by limiting their participation to passive victims in need of safety and security. ${ }^{23}$ According to the International Center for Transitional Justice report (2006), a 'Women's experience of political violence is often neglected in transitional justice approaches. Far too often, truth commission mandates, judicial opinions, and policy proposals for reparations and reform have been written, interpreted, and implemented with little regard

\footnotetext{
${ }^{16}$ Ibid.

${ }^{17}$ Roberts (2010: 115-35).

${ }^{18}$ Graybill (2017: 53-73).

${ }^{19}$ United Nations (2013).

${ }^{20}$ Graybill (2017: 53-73).

${ }^{21}$ United Nations (2009).

${ }^{22}$ United Nations (2000); ICRC (2019).

${ }^{23}$ Björkdahl \& Selimovic (2015: 165-82).
} 
for the distinct and complex injuries women have suffered. ${ }^{24}$ Hence, the critical feminist approach to advocating inclusion of human rights violations against women, gained momentum in a number of truth commissions in Africa, drawing attention to the need for a more holistic and inclusive approach to truth-telling processes in post-conflict settings.

\section{Critical feminism in truth commission processes}

This article applies critical feminism as a theoretical framework for understanding strategies that have been applied to integrate women's experiences of violence into the truth commission process. Feminist theories tend to be focused more on power relations, agency, individual or group experiences, socially constructed systems, and knowledge that tend to marginalise women's concerns. ${ }^{25}$ Feminist and critical theories seek to disrupt the comfort of the status quo while emphasising individual women's experiences as point of departure. Hence, critical feminism brings to consciousness issues around power imbalances, patriarchy, social justice, marginalised narratives, and cultural, racial, and political biases, while drawing attention to women's agency in driving the desired social change. ${ }^{26}$ Borrowing from Deborah Rhode's ${ }^{27}$ interpretation of application of critical feminism, a number of interpretive frameworks relevant to gendered perspectives in truth commissions can be deduced: on a political level, critical feminists seek to advocate for equal treatment between men and women in the design and implementation of the truth commissions. At the substantive level, critical feminists aim to make gender a focus of analysis in which specific legal frameworks within the truth commission processes are observed. This is crucial because the development of local and international legal frameworks that recognise human rights violations against women is crucial to the integration of gendered perspectives in truth commissions. On the methodological level, critical feminists aim at correcting ways in which truth commission processes have been conducted, without in-depth cognisance of the variation in female representation of cases of sexual and gender-based violence; as statement taking; and articulation of the findings of crimes against women.

Gender concerns are often reduced to constitute a subject matter of women and girls alone. Critical feminism takes a different approach, and draws attention to the

\footnotetext{
${ }^{24}$ (ICTJ 2006: 3).

${ }^{25}$ Acker et al. (1991: 423-35); see also Tisdell (1995).

${ }^{26}$ Collins (1990); see also Lather (1991).

${ }^{27}$ Rhode (1990: 617-38).
} 
fact that gender framing in transitional justice processes has tended to be patriarchal, with strong undertones of male dominance. Moreover, the reference to women's conflict experiences is often reduced to sexual violence, where women are portrayed unilaterally as victims. But the complexities in truth commission processes in terms of categorisation of crimes, identification of victims, truth-telling process, and witness interrogation are fundamental to the generation of gender-sensitive processes. While there are limitations on the extent to which truth commissions can conduct a full investigation into past crimes, they can nevertheless highlight differential gendered experiences of violence. Vasuki Nesiah et al. note that:

Truth commissions usually operate with a balance of probabilities test, rather than the harsher proof-beyond-doubt criteria required for most criminal prosecutions; thus, the evidentiary requirements are more victim friendly. Nevertheless, sensitivity to the embedded gender biases in rules of evidence and procedure is important when truth commissions make findings and establish the official record..$^{28}$

Consequently, by mainstreaming gender into the truth commissions, many women recognise that 'truth commissions can provide an extraordinary window of opportunity to highlight neglected abuses, research the enabling conditions of gendered violations, provide a forum for victims and survivors, recommend reparations that redress injustices, and leave a long-term legacy that is responsive to women's history and quest for reform'. ${ }^{29}$

\section{Gender-mainstreaming in truth commissions}

There has been a great push by different women's groups to consider gender mainstreaming in transitional justice processes, away from the androcentric approach in truth commissions that had dominated earlier truth-telling processes. Mainstreaming women's concerns in truth commissions implies the full integration of women's concerns - from the establishment of the mandate of the truth commission, appointing of commissioners, recruitment of staff to the collection of evidence, documentation, and public hearings, to the final report writing. The aim of these feminist perspectives is to focus on particular processes that incorporate gender into the corresponding actions, whether on training the commission and its staff on gender issues, or making sure that the writing of the truth commission reports pays attention to fundamental gender issues. ${ }^{30}$

\footnotetext{
${ }^{28}$ Nesiah et al. (2006: 23).

${ }^{29}$ ICTJ (2006: 2).

${ }^{30}$ Sarkin \& Ackermann (2019).
} 
Recent truth commissions in South Africa (1995), Burundi (1995), ${ }^{31}$ Nigeria (1999), Sierra Leone (2002), Ghana (2002), Liberia (2007), and Kenya (2013) made good attempts to integrate gender-based violence. However, from a critical feminist perspective, to attain high levels of consciousness on gender-related violence in truth commissions, it took consistent campaigns, consultations, and lobbying by feminist groups, civil society organisations, and human rights groups. For example, the Truth and Reconciliation Commission (TRC) in South Africa, which was the first and most prominent in Africa, held a limited purview on women's human rights violations, particularly given that it hardly probed the intersectional aspects of race, ethnicity, class, and gender. ${ }^{32}$ As will be discussed later, with persistent lobbying and advocacy, more attention was given to women's issues of concern by the South African TRC. Earlier commissions in Chile and Argentina hardly invoked gender perspectives in their approach to addressing historical crimes against humanity. ${ }^{33}$

In Ghana, Sierra Leone, and South Africa there were concerted efforts to integrate gender concerns into the truth commissions. For example, the National Reconciliation Commission (NRC) in Ghana did not mainstream gender issues in the first two years, but adopted gender concerns in its operations later on. ${ }^{34}$ This was a result of aggressive lobbying by women's groups and civil society organisations that raised concerns over the importance of including cases of violence against women. This was particularly important because women formed 42.9 per cent of the victims of sexual violence in Ghana. ${ }^{35}$ In the case of Sierra Leone, women comprised '100 percent of cases of sexual slavery and rape, and 38.5\% of cases of reported sexual abuse' ${ }^{36}$ In the 1996 elections and the peace settlement in 1999 (Lomé Peace Agreement) ${ }^{37}$, women played a crucial role in achieving peace by putting pressure on the leading warring parties to come to the negotiating table. ${ }^{38}$ Further, the women advocated for the inclusion of SGBV in the processes of the Truth and Reconciliation Commission (TRC). Gendering transition in Sierra Leone was therefore conceived from the beginning of the transitional justice process, instead of being a concession at a later stage.

\footnotetext{
${ }^{31}$ In 1995 the UN Security Council set up an International Commission of Inquiry for Burundi. The Commission was to investigate human rights violations related to the assassination of the former president, Melchior Ndadaye on 21 October 1993 as well as other massacres that took place during the same period. So, strictly speaking, this was not a truth commission. The commission interviewed 667 witnesses (United States Institute of Peace 1995a).

${ }^{32}$ Meintjes (2011: 97).

${ }^{33}$ ICTJ (2006: 3).

${ }^{34}$ Gyimah (2009).

${ }^{35}$ Nesiah et al. (2006: 23).

${ }^{36} \mathrm{Nesiah}$ et al. (2006).

${ }^{37}$ United Nations (1999).

${ }^{38}$ Sarkin \& Ackermann (2019).
} 
In the South African Truth and Reconciliation Commission (TRC), women accounted for 54.8 per cent of all the statements taken, while at the same time women represented only 43.9 per cent of the number of those who reported personal direct experiences of human rights violations. ${ }^{39}$ Helen Scanlon and Kelli Muddell, noted that in the South Africa's TRC process, in most cases, women told stories of other people (husbands, children, relatives, or friends) who had been victims of the apartheid system, rather than their own stories. ${ }^{40}$ Even when they had to tell their stories as victims of violence, they hardly got a platform to explain their role in the liberation struggle, even though to a great extent the TRC emerged as a 'microcosm of broader struggles' ${ }^{41}$ Hence, efforts by feminist groups to get women to articulate their experiences of violence was important. As a result, out of those women who reported direct experiences of violence, 85 per cent of them suffered severe maltreatment that affected them physically, psychologically, and economically. In total '446 statements coded as sexual abuse, 40 per cent of those in which the sex of the victim was specified reported the abuse of women'. ${ }^{42}$

The challenge with mainstreaming gender in all aspects of the truth commissions is the danger of pitting gender issues into opposition or competition with all other important issues. Most cases involving gross human rights violations have different social justice layers with diverse actors. A case concerning human rights violations could involve women both as victims and perpetrators, at the same time being embedded in historical injustices which the society has experienced over the years. Conducting contextual and historical research in order to 'provide a fuller understanding of the systematic aspects of the abuse of a particular political regime or political system" ${ }^{23}$ would highlight the complexities of the diverse issues at hand. It is therefore important to adopt ' $[a]$ multidimensional analysis of the community's fault lines and political struggles' ${ }^{44}$ Besides, even when the commissioners are trained on gender sensitivity upon recruitment, often the gender focus tends to fade away. In a number of commissions, 'the majority of commissioners and staff have not had extensive and rigorous exposure to the history of women's human rights abuse or even to a critical and vigilant approach to gender bias' ${ }^{45}$ For example, in the case of Peru's truth commission which had a gender unit, the individual commissioners and staff members were well exposed to the gender justice issues and some had worked with feminist movements,

\footnotetext{
${ }^{39}$ Kusakufa (2009).

${ }^{40}$ Scanlon \& Muddell (2010: 12).

${ }^{41}$ Meintjes (2011: 105).

${ }^{42}$ Kusakufa (2009).

${ }^{43}$ Ibid. (97).

${ }^{44}$ ICTJ (2006: 5).

${ }^{45}$ Nesiah et al. (2006).
} 
yet 'there appears to be wide consensus that a gender-conscious approach did not permeate the other units' everyday functioning' ${ }^{46}$ There is a general limitation on the extent to which gender issues can be integrated into truth commission processes. Despite these limitations, gender sensitivity ought to be a vital component of truth commissions.

\section{Critical feminist advocacy in truth commissions}

Critical feminism questions the different dimensions of social structures that perpetuate marginalisation of women. As such, critical feminist advocacy pays attention to strategies that can be applied to change structures of marginalisation, increase opportunities and participation of women in these structures, as well as pursue new frontiers for women to realise their goals in life. The discussion in this section will emphasise diverse perspectives and advocacy strategies in truth commissions that increase women's visibility and concerns around human rights violation against women. These include: ensuring women's participation in the membership of truth commissions; training commissioners to be gender sensitive in executing transitional justice processes; establishing a gender unit that addresses women's issues in the truth commission processes; developing legal frameworks, at both local and international levels, to address violence against women; and training statement takers and truth commission staff in accurate recording of human rights violations against women.

While it is debatable whether having women commissioners on truth commissions can make a difference in ensuring sensitivities on gender-based violence, it is at the same time important that visibility of women in the commission is encouraged. For the case of Sierra Leone, it was a requirement in the TRC Act that women be selected as commissioners of the TRC. This ultimately led to the appointment of three women commissioners, including a female deputy chair, out of seven members in total (43 per cent). ${ }^{47}$ The Women's Task Force, an umbrella organisation for women's groups and other local and international non-governmental organisations (NGOs) and civil society organisations focusing on women's rights, operated as a forum on the role of women in the TRC as well as in the Special Court of Sierra Leone. ${ }^{48}$ The activist advocacy approach by these women's organisations brought into the limelight concerns about violence against women survivors. In Liberia, of the nine commissioners of the Liberian TRC, four were women constituting 44.4 per cent. Three of them were

\footnotetext{
${ }^{46}$ Ibid. (4).

${ }^{47}$ Ibid.

${ }^{48}$ Ibid.
} 
drawn from a background that dealt with women's issues. In South Africa, commissioners were recruited in a consultative and transparent manner. Out of the seventeen members of the commission selected, eight were women drawn from the representatives of women's groups ${ }^{49}$ and NGOs as well as legislative representatives and scholars. These women collectively influenced the commission to include gendered perspectives in their mandate.

Equally important is the training of the commissioners of the truth commissions on the categorisation, representation, narration, documentation, and perception of women's experiences of violence. The training puts everyone in the commission at the level of understanding and interpretation of cases of violence against women. In the case of Sierra Leone, all commissioners, including a few employees of the TRC, were trained by international, transnational, and national women's organisations on women's issues related to the work of the truth commission. ${ }^{50}$ The TRC evaluated the impact of the conflict on women and promoted gender sensitivity, in particular with regard to the testimony of women witnesses and victims during public and closed hearings. Additionally, the female victims and witnesses were provided with psychosocial support and most women's groups expressed their confidence in the TRC because they had addressed gender issues. Since the Sierra Leonian TRC's concern was on how female victims could find a platform to express themselves and forge a common future through forgiveness and reconciliation, the commission recommended, 'changes in discriminatory laws that made women vulnerable to violence'. ${ }^{51}$ In Liberia, the TRC's induction prepared the commissioners and staff to pay special attention to the issue of sexual and gender violence, particularly children's and women's experiences during armed conflicts. ${ }^{52}$ The Commission's mandate included addressing sexual harassment and sensitivity to sex and gender-based abuses of human rights. Moreover, the Commission's composition, work, operations, and functions required gender mainstreaming. ${ }^{53}$

A special gender unit in truth commissions, focused on investigating and reporting human rights violations against women, is fundamentally important. Such a unit once established, focuses specifically on addressing differential gendered concerns in experiences of violence. For example, in Peru's truth commission, a special gender unit was established to look at the sexual and gender-based violence against women. ${ }^{54}$ The unit acquired a 'watchdog function for the commission' ensuring that gender matters were

\footnotetext{
${ }^{49}$ United States Institute of Peace (1995b).

${ }^{50}$ Ibid.

${ }^{51}$ Scanlon \& Muddell (2010: 11).

${ }^{52}$ Sarkin \& Ackermann (2019).

${ }^{53}$ Meintejes (2010: 89-93).

${ }^{54}$ Nesiah et al. (2006: 4).
} 
not marginalised. ${ }^{55}$ The Liberian TRC was the main mechanism for the mainstreaming of gender in its operations through a separate gender unit and an associated committee. ${ }^{56}$ The Gender Committee was set up as a separate organisation, consisting of women's groups and government officials. The Liberian TRC also held a hearing to which women's groups came to share their experiences of the civil war, and this was broadcast live on radio and television. Hence, the Liberian TRC gender-related work focused exclusively on women.

The South African TRC lacked a gender unit and from the onset did not consider gender issues separately, until later when feminist groups and other institutions raised awareness of the need to consider special category of women's cases of abuse. For example, the Women's National Coalition (WNC) called for a more integrated approach to addressing issues important to women at the TRC. ${ }^{57}$ Furthermore, the WNC demanded recognition of the roles that women play in society and how gendered discrimination and violence had affected them during the apartheid era. ${ }^{58} \mathrm{In}$ addition, a submission produced by University of Witwatersrand's Centre for Applied Legal Studies (CALS) following broad consultations with women's groups influenced the Commission's approach to the roles and experiences of women in and during apartheid. ${ }^{59}$ The submission by CALS indicated that there were differential representations of experiences of violence by both women and men during the apartheid period, and that it was important that the commission paid special attention to women. As a result, the Commission was persuaded to special consideration to women's cases, such as: 'holding special women's hearings, creating gender-sensitive statement-taking protocols, conducting research on gender, and having a chapter on women in the final report' ${ }^{\prime}{ }^{6}$ Consequently, public hearings on women's experiences of apartheid were organised and broadcast. Women who were scheduled to meet the killers of their sons and daughters received counselling and psychosocial support before going through the process. ${ }^{61}$ However, the commission had limited funding to accompany these women for a longer period after the traumatic experiences of meeting killers of their relatives, children, husbands, and friends.

Establishing legal frameworks that recognise sexual and gender-based violence is crucially important. Aili Tripp notes that post conflict countries have made tremendous efforts in including sexual and gender-based violence within legal frameworks

\footnotetext{
${ }^{55}$ Ibid.

${ }^{56}$ Ibid.

${ }^{57}$ Goetz (1998: 241-62).

${ }^{58}$ Ibid.

${ }^{59}$ Sarkin \& Ackermann (2019).

${ }^{60}$ Kusakufa (2009).

${ }^{61}$ Gobodo-Madikizela (2006).
} 
for effective prosecution of such crimes. ${ }^{62}$ In another study, Milli Lake underscores that a critical feminist approach by lobbyist civil society organisations and NGOs has contributed to the inclusion of SGBV among crimes for prosecution in the local courts of the Democratic Republic of Congo (DRC) ${ }^{63}$ At the international level, critical feminist lobbyists pushed for the inclusion of SGBV, amongst crimes against humanity. This was provoked by the fact that the ICC charged a rebel leader from the DRC, Thomas Lubanga, with forced recruitment of child soldiers, but excluded sexual enslavement despite the persistence of gender activists. Helen Scanlon and Kelli Muddell observe that two more DRC militia leaders, Germain Katanga and Mathiei Ngudjolo, were charged with crimes against humanity, excluding gender violence. ${ }^{64}$ Following strong feminist advocacy campaigns, sexual slavery charges were included and witnesses recruited. Up to 2014, a total of 63 per cent of the SGBV cases were confirmed by the ICC at the pretrial stages. ${ }^{65}$ There has, therefore, been an increased awareness at the level of ICC to include different categories of human rights violations against women. Today SGBV refers not only to violence against women, but also against men and children. On its policy paper on Sexual and Gender-Based Crimes, the ICC states that, 'The Office recognizes the need to strengthen its in-house expertise on sexual and gender-based crimes relating to women and girls, and men and boys, both in conflict and non-conflict situations. It will continue to recruit persons with the required expertise and experience in this field. ${ }^{66}$ This means the phenomenon of SGBV consciousness has gained positive attention at the ICC, and the organisation has been putting mechanisms into place to professionalise the response to SGBV cases. While there has been positive progress in addressing SGBV in post-conflict reconstruction processes, it is important to note that recognition of these crimes alone is insufficient. There is a need for a more systematic approach that will highlight gross human violations against women in truth commission processes.

An accurate recording of human rights abuses affecting women is crucial, increasing the prominence of SGBV in transitional justice processes. To achieve this, the persons who take statements from victims play an important role in truth-telling and should be gender sensitive in their recording of the statements. They should be trained in approaches to such recording, thereby deepening their ability to engage with different genders - as well as with different cultural, social, and political sensitivities - and the psychosocial status of the victims. In the transitional justice processes in Peru, Ghana, and Timor-Leste, the persons who took statements were trained in

\footnotetext{
${ }^{62}$ Tripp (2010: 7-20).

${ }^{63}$ Lake (2019).

${ }^{64}$ Scanlon \& Muddell (2010).

${ }^{65}$ Ibid.

${ }^{66}$ ICC (2014: 115).
} 
gender sensitivity and consciousness. In Timor-Leste, 'organizing its householdmortality survey, the Commission included at least one woman in each research team who conducted a separate interview with at least one adult woman in every household' ${ }^{67}$ This demonstrates that it is important to take into account the fact that, in some cases, female victims prefer to talk to fellow women about their experiences of human rights violations. Hence, the commission has to be sensitive to this fact in the statement-taking process.

While the above discussion has largely focused on the live period of the commission's mandate, it is important to consider the impact of the truth-telling process on women survivors of violence, especially after the process is over. ${ }^{68}$ This is because the post-truth-commission period often exposes victims of human rights violations to possible backlash, which can re-victimise them. A study by Karen Brounéus on women witnesses at the Rwanda gacaca truth-telling process indicates that women who tell their stories of abuse and torture can later be pursued by their perpetrators, causing more injury to persons who are already vulnerable. ${ }^{69}$ Furthermore, the traumatic experiences of truth-telling processes have sometimes led to post-traumatic stress disorder that prevents healing and reconciliation. ${ }^{70}$

In addition, it is important to note that the process of truth-telling and truthseeking ought to be viewed as a dialectical process - where the victims tell their stories, encounter their perpetrators, and develop mechanisms for coexistence, either through reparation, reconciliation, or compensation. The commission's mandate may not extend to assisting victims in finding justice and resettlement, but it should propose mechanisms for supporting the victims. In principle, it is the task of government to ensure that victims are supported in the post-commission period.

\section{Conclusion}

The analysis of processes of truth commissions discussed in this article indicates that it had to take a critical feminist advocacy to incorporate women's concerns in the proceedings of the commissions. While men and women suffer differently in situations of conflict, women tend to be highly vulnerable to more extreme abuses than men. Highlighting women's experiences of violence in truth commission processes seeks to attain a more holistic approach to addressing human rights violations. This is

\footnotetext{
${ }^{67}$ ICTJ (2006: 19).

${ }^{68}$ Ephgrave (2015).

${ }^{69}$ Brounéus (2008: 55-76).

${ }^{70}$ Brounéus (2010: 408-27).
} 
particularly important given that truth-telling and testimonies of survivors are of great value to healing a nation and realising social cohesion. Hence, truth commissions provide a positive platform that can highlight the major concerns relating to the marginalisation of women.

Women's participation in truth commissions as agents of execution of the truth-telling process is equally important. As such, there is a need to have significant representation of women commissioners and staff, while paying attention to their qualifications, passion, and commitment. Such women work as personnel for gender units, statement-takers, or researchers on women's and gender issues. However, it is not enough to simply have women as commissioners or in leadership positions without substantial transformation of structures of violence and marginalisation against women.

At the core of truth commission processes is the desire to have a different nation where inclusion, justice, respect, dignity, and equity are experienced and shared by all. Truth commissions are by themselves limited in realising such a transformation, but provide a good platform for initiation of particular reforms that can move the nation onto a new page. Social-political accountability is one of the key desired achievements of truth commissions, particularly in relation to respect of human rights, and in the case of discussion in this article, protection of the rights of women at different levels of society.

\section{References}

Acker, J. (1991), 'Thinking about Wages: The Gendered Wage Gap in Swedish Banks', Gender \& Society, 5: 390-407. https://doi.org/10.1177/089124391005003008

African Union (2019), Transitional Justice Policy (Addis Ababa, African Union).

Bakiner, O. (2016), Truth Commissions: Memory, Power, and Legitimacy (Philadelphia, PA, University of Pennsylvania Press). https://doi.org/10.9783/9780812291926

Björkdahl, A. \& Selimovic, J.M. (2015), 'Gendering Agency in Transitional Justice', Security Dialogue, 46(2): 165-82. https://doi.org/10.1177/0967010614552547

Brounéus, K. (2008), 'Truth-Telling as Talking Cure? Insecurity and Retraumatization in the Rwandan Gacaca Courts', Security Dialogue, 39(1): 55-76. https://doi.org/10.1177/0967010607086823

Brounéus, K. (2010), 'The Trauma of Truth Telling: Effects of Witnessing in the Rwandan Gacaca Courts on Psychological Health', The Journal of Conflict Resolution, 54(3): 408-37. https://doi.org/10.1177/0022002709360322

Collins, P.H. (1990), Black Feminist Thought, Knowledge, Consciousness, and the Politics of Empowerment (Boston, MA, Unwin Hyman).

Denov, M.S. (2006), 'Wartime Sexual Violence: Assessing a Human Security Response to War-affected Girls in Sierra Leone', Security Dialogue, 37(3): 319-42.

https://doi.org/10.1177/0967010606069178 
Ephgrave, N. (2015), 'Women's Testimony and Collective Memory: Lessons from South Africa's TRC and Rwanda's Gacaca Courts', European Journal of Women's Studies, 22(2): 177-90. https://doi.org/10.1177/1350506814547057

Freeman, M. (2006), Truth Commissions and Procedural Fairness (Cambridge, Cambridge University Press). https://doi.org/10.1017/CBO9780511584473

Gobodo-Madikizela, P. (2006), A Human Being Died That Night: Confronting Apartheid's Chief Killer (London, Portobello).

Goetz, A.M. (1998), 'Women in Politics \& Gender Equity in Policy: South Africa \& Uganda', Review of African Political Economy, 25(76): 241-62. https://doi.org/10.1080/03056249808704312

Graybill, L.S. (2017), Religion, Tradition, and Restorative Justice in Sierra Leone (Bloomington, IN, University of Notre Dame Press). https://doi.org/10.2307/j.ctvpj7dnn

Gyimah, A. (2009), 'Gender and Transitional Justice in West Africa: The Cases of Ghana and Sierra Leone', ALC Research Report No. 4, August. https://www.africanleadershipcentre.org/attachments/ article/43/ALC $\% 20$ Report $\% 20$ No.\%204\%20Gyimah.pdf

Hayner, P.B. (2001), Unspeakable Truths: Confronting State Terror and Atrocity (New York, Routledge). https://doi.org/10.4324/9780203903452

Human Rights Watch (2003), 'We'll Kill You If You Cry: Sexual Violence in the Sierra Leone Conflict'. http://www.hrw.org/reports/2003/sierraleone/ [accessed 22 February 2021].

ICC (International Criminal Court) (2014), 'Policy Paper on Sexual and Gender-based Crimes' (Geneva, International Criminal Court).

ICRC (International Committee of the Red Cross) (2019), 'ICRC Statement on Women, Peace and Security'. https://www.icrc.org/en/document/icrc-statement-women-peace-and-security-wps [accessed 12 January 2021].

ICTJ (International Center for Transitional Justice) (2006), Truth Commissions and Gender: Principles, Policies, Procedures (New York, International Center for Transitional Justice).

ICTJ (International Center for Transitional Justice) (n.d.), 'What is Transitional Justice'. https://www.ictj.org/about/transitional-justice [accessed 2 March 2021].

Kandiyoti, D. (1988), 'Bargaining with Patriarchy', Gender \& Society, 2(3): 274-90. https://doi.org/10.1177/089124388002003004

Kusakufa, A. (2009), 'Truth Commission and Gender: A South African Case Study', Africa Journal of Conflict Resolution, 2. https://www.accord.org.za/ajer-issues/truth-commissions-and-gender/; https://doi.org/10.4314/ajcr.v9i2.52172 [accessed on 12 February 2021].

Lake, M. (2019), Strong NGOs and Weak States: Pursuing Gender Justice in the Democratic Republic of the Congo and South Africa (Cambridge, Cambridge University Press). https://doi.org/10.1017/9781108297745

Lather, P. (1991), Getting Smart, Feminist Research and Pedagogy with/in the Postmodern (New York, Routledge). https://doi.org/10.4324/9780203451311

Meintjes, S. (2010), 'Gender and Truth and Reconciliation Commissions: Comparative Reflections', in C.L. Sriram \& S.P. Sriram (eds) Peace Versus Justice? The Dilemma of Transitional Justice in Africa (Woodbridge, James Currey).

Nesiah, V. et al. (2006), Gender, Women, and Truth Commissions: The Canadian and South African Truth and Reconciliation Commissions (New York, International Center for Transitional Justice).

Olsen, T.D., Payne, L.A. \& Reiter, A.G. (2010), 'The Justice Balance: When Transitional Justice Improves Human Rights and Democracy', Human Rights Quarterly, 32(4): 980-1007. https://doi.org/10.1353/hrq.2010.0021

Pankhurst, D. (2007), Gender Issues in Post-war Contexts: A Review of Analysis and Experience, and Implications for Policies (Bradford, University of Bradford).

Pettman, J. (1996), Worlding Women: A Feminist International Politics (London, Routledge). 
Rhode, D.L. (1990), 'Feminist Critical Theories', Stanford Law Review, 42(3): 617-38. https://doi.org/10.2307/1228887

Roberts, A. (2010), 'Lives and Statistics: Are 90\% of War Victims Civilians?', Survival, 52(3): 115-36. https://doi.org/10.1080/00396338.2010.494880

Sarkin, J. \& Ackermann, S. (2019), 'Understanding the Extent to which Truth Commissions are Gender Sensitive and Promote Women's Issues: Comparing and Contrasting these Truth Commission Roles in South Africa, Guatemala, Peru, Sierra Leone and Liberia'. https://www.law.georgetown. edu/international-law-journal/wp-content/uploads/sites/21/2019/10/GT-GJIL190031.pdf [accessed 20 June 2020].

Scanlon, H. \& Muddell, K. (2010), 'Gender and Transitional Justice in Africa: Progress and Prospects', African Journal on Conflict Resolution, 9(2): 9-27. https://doi.org/10.4314/ajcr.v9i2.52170

Tisdell, E. (1995), Creating Inclusive Adult Learning Environments: Insights from Multicultural Education and Feminist Pedagogy (Darby, PA, Diane Publishing).

Tripp, A.M. (2010) 'Legislating Gender-based Violence in Post-conflict Africa', Journal of Peacebuilding \& Development, 5(3): 7-20. https://doi.org/10.1080/15423166.2010.981435347428

United Nations (n.d.), 'Responsibility to Protect'. https://www.un.org/en/genocideprevention/about-responsibility-to-protect.shtml [accessed 1 March 2021].

United Nations (1999), Peace Agreement between the Governement of Sierra Leone and the RUF (Lomé Peace Agreement). https://peacemaker.un.org/sierraleone-lome-agreement99

United Nations (2000), UN Security Resolution 1325. https://documents-dds-ny.un.org/doc/UNDOC/ GEN/N00/720/18/PDF/N0072018.pdf?OpenElement

United Nations (2009), UN Security Resolution 1889. https://undocs.org/en/S/RES/1889(2009)

United Nations (2013), UN Security Council Resolution 2106 (On Sexual Violence in Armed Conflict). https://digitallibrary.un.org/record/751023? ln=en

United States Institute of Peace (1995a), 'Commission of Inquiry: Burundi'. https://www.usip.org/publications/1995/09/commission-inquiry-burundi

United States Institute of Peace (1995b), 'Truth Commission: South Africa'. https://www.usip.org/publications/1995/12/truth-commission-south-africa

Wiebelhaus-Brahm, E. (2010), Truth Commissions and Transitional Societies: The Impact on Human Rights and Democracy (London, Routledge). https://doi.org/10.4324/9780203862025

To cite the article: Elias O. Opongo (2021), 'Gendering transitional justice processes in Africa: a feminist advocacy approach to truth commissions', Journal of the British Academy, 9(s2): 35-52.

DOI https://doi.org/10.5871/jba/009s2.035

Journal of the British Academy (ISSN 2052-7217) is published by The British Academy, 10-11 Carlton House Terrace, London, SW1Y 5AH www.thebritishacademy.ac.uk 